\title{
PENGARUH CITRA MEREK DAN HARGA TERHADAP LOYALITAS PELANGGAN SEPATU MEREK NIKE DI SINGARAJA FUTSAL
}

\author{
Ahmad Samsul Rizal ${ }^{1}$, Ni Luh Wayan Sayang Telagawathi²,Ni Nyoman Yulianthini ${ }^{3}$, \\ Komang Endrawan Sumadi Putra ${ }^{4}$ \\ 1,2,3,4 Jurusan Manajemen, Universitas Pendidikan Ganesha, Singaraja \\ e-mail: ahmdsamsulrizal@gmail.com ${ }^{1}$, gemilangsuryawan@gmail.com² ${ }^{2}$, ninymyulianthini@gmail.com³ \\ kmendrawan.sp@gmail.com ${ }^{4}$
}

\begin{abstract}
Abstrak
Penelitian ini bertujuan untuk menguji pengaruh citra merek dan harga terhadap loyalitas pelanggan, baik secara simultan maupun secara parsial. Desain penelitian yang digunakan dalam penelitian ini adalah kuantitatif kausal. Metode yang digunakan adalah metode Survey. Subjek dalam penelitian ini adalah Singaraja Futsal di Kota Singaraja dan objek dalam penelitian ini adalah citra merek, harga dan loyalitas pelanggan. Populasi dalam penelitian ini yaitu pengguna sepatu merek Nike yang berada di Singaraja Futsal dengan melibatkan 70 responden. Data dikumpulkan dengan kuesioner, dan dianalisis dengan analisis regresi linier berganda. Hasil penelitian menunjukkan bahwa (1) citra merek dan harga berpengaruh signifikan terhadap loyalitas pelanggan, (2) citra merekberpengaruh positif dan tidak signifikan terhadap loyalitas pelanggan, dan (3) harga berpengaruh positif dan tidak signifikan terhadap loyalitas pelanggan sepatu merek Nike di Singaraja Futsal.
\end{abstract}

Kata kunci : citra merek, harga, loyalitas pelanggan

\begin{abstract}
This study aims to examine the effect of brand image and price on customer loyalty, both simultaneously and partially. The research design used in this study is quantitative causal. The method used is the Survey method. The subjects in this study were Singaraja Futsal in Singaraja City and the objects in this study were brand image, price and customer loyalty. The population in this study were users of Nike brand shoes in Singaraja Futsal involving 70 respondents. Data were collected by questionnaire, and analyzed by multiple linear regression analysis. The results showed that (1) brand image and price had a significant effect on customer loyalty, (2) brand image had a positive and not significant effect on customer loyalty, and (3) price had a positive and not significant effect on customer loyalty for Nike brand shoes in Singaraja Futsal.
\end{abstract}

Keywords: brand image, customer loyalty, price 


\section{PENDAHULUAN}

Perkembangan industri sepatu saat ini cenderung mengalami kenaikan, seiring perkembangan perusahaan yang mengeluarkan produk sejenis. Peningkatan indutsri sepatu menjadi peluang besar bagi para produsen sepatu mengingat Indonesia adalah negara dengan salah satu jumlah penduduk terbanyak di dunia. Produsen sepatu akhirnya berlomba-lomba untuk memproduksi sepatu yang menarik agar pelanggan berminat untuk membelinya. Sejalan dengan perkembangan industri yang terjadi, pelanggan juga mengalami perkembangan. Hal ini terlihat bahwa semakin lama pelanggan semakin kritis dalam memilih suatu merek. Banyaknya promosi yang menghampiri pelanggan semakin memudahkan para pelanggan untuk menentukan pilihannya sesuai dengan keinginan pelanggan sehingga para produsen harus tetap memperhatikan kondisi para pelanggan mereka agar tetap loyal pada merek mereka.

Berbicara tentang loyalitas pelanggan, dalam hal ini tidak terlepas dari faktor yang menyebabkan timbulnya kesenjangan dalam loyalitas pelanggan tersebut. Pelanggan akan loyal terhadap sebuah merek apabila citra sebuah merek tersebut benar-benar terkesan oleh kalangan pelanggan, akan tetapi harga akan berpengaruh terhadap loyalitas pelanggan apabila harga yang di tetapkan sesuai dengan kemampuan daya beli pelanggan. Loyalitas pelanggan merupakan komitmen pelanggan terhadap suatu merek, toko, pemasok berdasarkan sikap yang sangat positif dan tercermin dalam pembelian ulang yang konsisten.(Tjiptono, 2000:110). Penggunaan terhadap suatu merek yang terkenal akan menentukan kelas sosial seorang pelanggan memakai sebuah merek. Pentingnya membentuk kepercayaan diri seseorang dapat ditentukan apabila memakai sebuah merek yang terkenal. Pelanggan yang ingin mempunyai hak milik produk terkenal tidak semudah membalikkan telapak tangan, namun harus membeli dengan nilai tukar yang cukup tinggi sebagai ganti mendapatkan pengakuan mempunyai produk yang citra mereknya terakui oleh masyarakat.

Aaker (2008) menyatakan, merek adalah sebuah nama ataupun simbol yang bertujuan untuk membedakan dan mengidentifikasi barang atau jasa dari salah satu penjual ataupun sekelompok penjual yang merupakan pesaing mereka. Selain itu sebuah merek juga dapat menjadi sebuah sinyal bagi pelanggan atas sebuah produk, dan melindungi baik pelanggan maupun produsen dari pesaing yang akan berusaha untuk menyediakan produk identik yang akan muncul.

Diketahui bahwa citra merek yang terkenal tidaklah lepas dari harga yang mahal, pengaruh harga sangat menentukan loyalitas pelanggan terhadap sebuah produk. Penetapan harga yang di tentukan oleh perusahaan akan memilah kalangan masyarakat yang akan mampu mempunyai sebuah produk yang berkualitas dengan citra yang diakui bagus oleh masyarakat akan terhambat oleh harga sebuah produk yang terlalu mahal. Harga adalah sejumlah uang yang harus dibayar oleh pelanggan untuk memperoleh produk (Kotler, 2000: 73).

Nike adalah salah satu dari sekian banyak jenis perusahaan yang memproduksi produk sepatu. Nike merupakan salah satu pemimpin produk sepatu di pasar ditengah-tengah kondisi pasar yang semakin ketat persaingannya karena semakin banyak pesaing lainnya yang mengeluarkan produk sejenis seperti merek Adidas, Puma dan Reebok. Nike juga memberikan citra merek yang berbeda kepada para konsumen jika dibandingkan dengan para pesaing lainnya misalnya saja dengan melakukan promosi pada media yang mudah ditemukan para konsumen, klub-klub olah raga juga sering kali disponsori oleh pihak Nike bahkan Nike membuka toko-toko khusus untuk merek mereka di pusat-pusat perbelanjaan sehingga konsumen semakin mudah untuk memilikinya. Perusahaan Nike harus dapat bersaing dan dapat terus bertahan guna mencapai tujuan yang diinginkan oleh perusahhan.

Perusahaan harus memiliki suatu keunggulan kompetitif agar dapat terus tumbuh berkembang, serta perusahaan dapat memberikan manfaat sebesar-besarnya bagi pemilik serta para pemegang kepentingan perusahaan. Perusahaan-perusahaan tersebut adalah PT. Nike Indonesia Tbk. PT. Adidas Indonesia. PT Mitra Adi Perkasa Tbk (MAPI) dan J.W Foster \& Sons.Masing-masing perusahaan tersebut menawarkan produk sepatu dengan merek, harga keunggulan yang berbeda-beda. Merek yang ditawarkan perusahaan-perusahan tersebut 
diantaranya, Nike, Adidas, Puma, Reebok. Kondisi tersebut menimbulkan persaingan yang ketat diantara perusahaan-perusahaan sejenis yang menawarkan produk yang sama, maka dari itu perusahaan dituntut untuk melakukan berbagai upaya untuk meraih pangsa pasar terbesar.

Nike adalah salah satu dari sekian banyak jenis perusahaan yang memproduksi produk sepatu. Nike merupakan salah satu pemimpin produk sepatu di pasar ditengah-tengah kondisi pasar yang semakin ketat persaingannya karena semakin banyak pesaing lainnya yang mengeluarkan produk sejenis seperti merek Adidas, Puma dan Reebok. Nike juga memberikan citra merek yang berbeda kepada para konsumen jika dibandingkan dengan para pesaing lainnya misalnya saja dengan melakukan promosi pada media yang mudah ditemukan para konsumen, klub-klub olah raga juga sering kali disponsori oleh pihak Nike bahkan Nike membuka toko-toko khusus untuk merek mereka di pusat-pusat perbelanjaan sehingga konsumen semakin mudah untuk memilikinya. Perusahaan Nike harus dapat bersaing dan dapat terus bertahan guna mencapai tujuan yang diinginkan oleh perusahhan.

Perusahaan harus memiliki suatu keunggulan kompetitif agar dapat terus tumbuh berkembang, serta perusahaan dapat memberikan manfaat sebesar-besarnya bagi pemilik serta para pemegang kepentingan perusahaan. Perusahaan-perusahaan tersebut adalah PT. Nike Indonesia Tbk. PT. Adidas Indonesia. PT Mitra Adi Perkasa Tbk (MAPI) dan J.WFoster \& Sons.Masing-masing perusahaan tersebut menawarkan produk sepatu dengan merek, harga keunggulan yang berbeda-beda. Merek yang ditawarkan perusahaan-perusahan tersebut diantaranya, Nike, Adidas, Puma, Reebok. Kondisi tersebut menimbulkan persaingan yang ketat diantara perusahaan-perusahaan sejenis yang menawarkan produk yang sama, maka dari itu perusahaan dituntut untuk melakukan berbagai upaya untuk meraih pangsa pasar terbesar.

Berdasarkan Top Brand Indeks sepatu, bahwa sepatu merek Nike masuk dalam Top Brand yang tergolong mengalami penurunan pada 2 tahun terakhir yaitu tahun 2016-2018. Tanggapan awal pada pengguna sepatu merek nike di Singaraja Futsal, telah dilakukan observasi awal pada 7 Juni 2018 terhadap 10 orang responden dengan usia 17 tahun - 40 tahun yang telah menggunakan sepatu merek Nike. Observasi awal dilakukan untuk mengetahui seberapa loyal pengguna kususnya terhadap sepatu merek Nike. Berikut hasil observasi awal yang dilakukan di singaraja futsal. Berdasarkan hasil observasi awal citra merek, harga dan loyalitas pelanggan pada pengguna sepatu merek Nike di Singraja Futsal bahwa sebagian besar responden dapat di kategorikan sedang,sesuai dengan hasil top brand indeks pada Tabel 1.1, dimana sepatu merek nike mengalami penurunan penjualan mulai tahun 2016-2018.

Dapat dilihat bahwa citra merek dan harga sangat berpengaruh terhadap loyalitas pelanggan. Adanya persaingan sebagai pengganti nilai pakai dapat memberikan kepuasan tersendiri bagi pelanggan. Kepuasan pelanggan diperoleh apabila apa yang didapatkan pelanggan sesuai dengan apa yang diharapkan. Jika pelanggan merasa puas dengan salah satu merek sepatu yang mereka gunakan maka tidak menutup kemungkinan pelanggan akan menjadi loyal dan susah untuk berpindah ke merek yang lain.

Data empiris tentang variabel bebas yang di duga mempengaruhi loyalitas pelanggan produk sepatu merek Nike dapat dilihat pada penelitian terdahulu yang dilakukan oleh Alif (2016) menyimpulkanbahwa citra merek, harga dan promosi berpengaruh positif dan signifikan terhadap loyalitas pelanggan produk jasa Tour dan Trevel PT Roda Express Sukses Mandiri. Begitu juga dengan penelitian yang dilakukan oleh Nalsen (2017), yang menyimpulkan bahwa citra merek dan harga berpengaruh positif dan signifikan terhadap loyalitas pelanggan pada air minum dalam kemasan.

Berdasarkan hasil observasi yang dilakukan di Singaraja Futsal dengan pengguna sepatu merek Nike, bahwa kurangnya loyalitas terhadap sepatu merek Nike dikarenakan citra merek yang berkelas tinggi dan harga yang terlalu mahal menjadi faktor utama penyebab 
melemahnya loyalitas pelanggan terhadap sepatu merek Nike. Masalah ini cenderung berkelanjutan karena kurang adanya upaya dari pemasar produk memahami strategi dalam pemasaran sepatu merek Nike.

Berdasarkan rumusan masalah diatas, tujuan penelitian ini adalah sebagai berikut1. Menguji pengaruh citra merek dan harga secara simultan terhadap loyalitas pelanggan produk sepatu merek Nike di Singaraja Futsal.2.Menguji pengaruh citra merek secara parsial terhadap loyalitas produk sepatu merek Nike di Singaraja Futsal. 3. Menguji pengaruh harga secara parsial terhadap loyalitas pelanggan produk sepatu merek Nike di Singaraja Futsal.

Hasil dari penelitian ini diharapkan dapat menjadi salah satu bahan pengembangan ilmu pengetahuan dalam bidang ilmu manajemen pemasaran khususnya yang berkaitan dengan citra merek dan harga terhadap loyalitas pelanggan dan memberikan sumbangan pemikiran bagi pihak pemasar produk sepatu merek Nike dalam penentuan strategi citra merek dan harga yang berpengaruh terhadap loyalitas pelanggan.

Untuk mengukur keberhasilan pemasaran dapat dilihat dari loyalitas pelanggan terhadap suatu citra merek dan harga. Menurut Tjiptono, (2000:110) loyalitas pelanggan sebagai komitmenpelanggan terhadap suatu merek, toko, pemasok berdasarkan sikap yang sangat positif dan tercermin dalam pembelian ulang yang konsisten. Harga adalah sejumlah uang yang harus dibayar oleh pelanggan untuk memperoleh produk (Kotler dan Amstrong, 2000:73). $\mathrm{Hal}$ ini sejalan dengan penelitian yang dilakukan Alif (2006) yang menyatakan bahwa citra merek dan harga secara simultan berpengaruh positif dan signifikan terhadap loyalitas pelanggan. Dari pemaparan tersebut maka dapat dirumuskan hipotesis sebagai berikut:

$\mathrm{H} 1$ : Ada pengaruh citra merek dan harga secara simultan terhadap loyalitas pelanggan pada Sepatu Nike di Singaraja Futsal.

Dalam melakukan keputusan pembelian konsumen memilih produk yang akan di beli, salah satu faktor adalah citra merek. Saladin (2006) menyatakan bahwa, Citra merek menjadi hal yang sangat penting diperhatikan perusahaan, melalui citra merek yang baik, maka dapat menimbulkan nilai emosional pada diri konsumen, dan akan timbul perasaan positif (positive feeling) pada saat membeli atau menggunakan suatu merek. Sebaliknya apabila suatu merek memiliki citra (image) yang buruk dimata konsumen, kecil kemungkinan konsumen untuk loyal terhadap produk tersebut.Oleh sebab itu, tinggi rendahnya loyalitas konsumen tergantung pada citra dari merek itu sendiri. Citra merek memberikan dorongan khusus kepada pelanggan untuk loyal akan suatu produk. Dari pemaparan tersebut maka dapat dirumuskan hipotesis sebagai berikut:

H2: Ada pengaruh citra merek secara parsial terhadap loyalitas pelanggan pada Sepatu Nike di Singaraja Futsal.

Helgensen (2006), menyatakan ada banyak faktor yang mempengaruhi loyalitas pelanggan seperti sensivitas harga yang memimpin terhadap profitabilitas yang memiliki hubungan langsung dengan loyalitas pelanggan. Harga merupakan variabel yang dapat dikendalikan dan menentukan diterima atau tidaknya suatuproduk oleh konsumen. Karena harga merupakan salah satu atribut paling penting yang dievaluasi oleh konsumen. Konsumen yang sadar akan harga produk akan tahu kualitas barang yang mereka terima sesuai jumlah uang yang dikorbankan. Namun tidak jarang konsumen menuntut alternatif harga yang lebih murah dengan kondisi produk yang sama.Perusahaan perlu memonitor harga yang ditetapkan oleh para pesaing agar harga yang ditentukan oleh perusahaan tidak terlalu tinggi atau sebaliknya, sehingga harga yang ditawarkan dapat menimbulkan keinginan konsumen untuk setia terhadap produk. Karena loyalitas yang terbentuk dari pelanggan pun akan mampu berubah ketika perusahaan menetapkan kebijakan harga yang menurut konsumen sudah tidak masuk akal lagi. Dari pemaparan tersebut maka dapat dirumuskan hipotesis sebagai berikut:

H3: Ada pengaruh harga secara parsial terhadap loyalitas pelanggan pada sepatu Nike di Singaraja Futsal. 


\section{METODE}

Penelitian ini menggunakan desain kuantitatif kausal. Menurut Sugiyono (2014:56) penelitian kausal adalah suatu penelitian yang mencari hubungan antara satu variabel dengan variabel yang lain yang mempunyai hubungan sebab akibat. Desain penelitian kuantitatif kausal dapat dilakukan dengan langkah-langklah yaitu (1) merumuskan masalah, (2) mengkaji teori, (3) merumuskan hipotesis, (4) mengumpulkan data, (5) menganalisis data, dan (6) membuat kesimpulan dan saran (Sugiyono,2014). Dalam penelitian ini variabel bebas adalah citra merek $\left(\mathrm{X}_{1}\right)$, harga $\left(\mathrm{X}_{2}\right)$, sedangkan variabel terikat adalah loyalitas pelanggan $(\mathrm{Y})$ di Singaraja Futsal 2016-2018.

Subjek dalam penelitian ini adalah pemain futsal di Singaraja Futsal. Pengguna produk sepatu merek Nike. Sedangkan objek dalam penelitian ini adalah citra merek, harga dan loyalitas pelanggan di Singaraja Futsal. Populasi dalam penelitian ini adalah pengguna sepatu Nike yang berada di Singaraja Futsal. Metode penentuan sampel yang digunakan dalam penelitian ini adalah metode purposive sampling, yaitu teknikpenentuan sampel dengan beberapa pertimbangan/tujuan tertentu. Ketentuan penelitian sampel pada penelitian ini adalah konsumen yang menggunakan produk sepatu Nike, dengan pertimbangan dianggap memahami dan mampu menjawab kuesioner secara cek list $(\sqrt{ })$. Ferdinand (2006), menyatakan bahwa banyaknya jumlah sampel dalam penelitian tergantung dari jumlah parameter yang diestimasi. Pedomannya adalah 5-10 kali jumlah pernyataan yang diestimasi. Dalam penelitian ini syarat responden menggunakan 14 indikator sehingga banyaknya responden yang diambil sebagai sampel adalah $5 \times 14$ item pernyataan $=70$ responden, jadi peneliti menggunakan jumlah sampel minimum yaitu 70 responden.

Instrumen pengumpulan data yang digunakan dalam penelitian ini adalah kuesioner yang berisi daftar pertanyaan yang akan disebarkan kepada responden. Kuesioner dirancang dengan skala likert. Skala likert adalah skala yang dapat digunakan untuk mengukur sikap, pendapat, dan persepsi seseorang tentang suatu obyek atau fenomena. Skala likert memiliki dua bentuk pernyataan, yaitu pernyataan positif dan negatif (siregar, 2013).

Metode analisis data yang digunakan dalam penelitian ini adalah analisis regresi linier berganda. Analisis regresi linier berganda digunakan untuk mengetahui ada tidaknya pengaruh signifikan antara satu atau lebih variabel bebas terhadap variabel terikat baik secara simultan atau parsial. Dalam penelitian ini peneliti ingin menguji dan menjelaskan hubungan dan arah pengaruh beberapa variabel bebas yang diteliti yaitu citra merek dan harga terhadap loyalitas pelanggan. Metode pengolahan data dalam penelitian ini menggunakan alat bantu komputer Statistical Package for Social Science (SPSS) versi 16.0 for windows untuk mempermudah peneliti dalam menganalisis data serta hasil yang diperoleh agar lebih akurat

\section{HASIL DAN PEMBAHASAN \\ HASIL PENELITIAN}

Penjelasan dari hasil analisis regresi linier berganda sebagai berikut:(1) Konstanta sebesar 63,629 artinya bahwa apabila citra merek dan harga, nilainya sama dengan nol, maka loyalitas pelanggan 63,629. (2) Nilai koefisien regresi citra merek sebesar 0,216 berpengaruh positif terhadap loyalitas pelanggan. Hal ini mengandung arti bahwa setiap kenaikan citra merek satu satuan maka loyalitas pelanggan mengalami peningkatan sebesar 0,216 sehingga loyalitas pelanggan menjadi 63,845 dengan asumsi bahwa variabel lainya tetap. (3) Nilai koefisien regresi harga sebesar 0,032 berpengaruh positif terhadap loyalitas pelanggan. Hal ini mengandung arti bahwa setiap kenaikan harga satu satuan maka loyalitas pelanggan mengalami peningkatan sebesar 0,032 sehingga loyalitas pelanggan menjadi 63,661 dengan asumsi bahwa variabel lainya tetap.

\section{PEMBAHASAN}

Berdasarkan penelitian yang telah dilakukan, hasil penelitian ini menunjukkan bahwa secara simultan variabel beabas yaitu citra merek dan harga berpengaruh signifikan terhadap loyalitas pelanggan di Singaraja Futsal. Hasil ini menunjukkan apabila variabel citra merek dan 
harga mengalami kenaikan secara bersama-sama maka diikuti dengan kanaikan loyalitas pelanggan. Hal ini berarti loyalitas pelanggan di Singaraja Futsal mesti memperhatikan citra merek dan harga untuk meningkatkan loyalitas pelanggan.

Menurut Kotler Dan Keller (2009) mendefinisikan citra merek sebagai refleksi memori konsumen akan asosiasinya terhadap merek tersebut. Sedangkan menurut Fandy Tjiptono (1997) citra merek adalah gambaran tentang asosiasi dan keyakinan konsumen terhadap suatu merek tertentu. Berdasarkan uraian diatas dapat disimulkn bahwa citra merek berpengarih terhadap loyalitas pelanggan. Dengan citra merek yang baik, pelanggan akan yakin dan percaya kepada produk atau jasa yang di tawarkan oleh sutu perusahaan sehingga tidak ada keraguan untuk memilih dan memutuskan pembelian produk.

Faktor harga juga berpengaruh terhadap loyalitas pelanggan seperti halnya menurut (Swasta, 1997) dalam pemasaran

terdapat juga penyesuaian dan koordinasi antara produk, harga, dan promosi untuk menciptakan hubngan pertukaran yangkuat dengan konsumen. Sedangkan menurut (Tjiptono 2000) strategi pemsaran tersebut mencakup rencana penempatan produk, perincian harga produk dan sasaran harga panjang dalam penjualan. Berdasarkan teori tersebut faktor harga dapat mempengaruhi loyalitas pelanggan terhadap suatu merek produk. Hasil ini diperkuat dengan penelitian yang dilakukan oleh Alif Indra Waskita (2016). Pengaruh citra merek, harga dan promosi terhadap loyalitas pelanggan. Menunjukkan hasil bahwa citra merek, harga dan promosi memberikan pengaruh positif dan signifikan terhadap loyalitas pelanggan.

Berdasarkan penelitian yang telah dilakukan menunjukkan bahwa citra merek berpengaruh positif dan tidak signifikan terhadap loyalitas pelanggan di Singaraja Futsal. Hasil ini menunjukkan dengan pertumbuhan citra merek yang meningkat akan berdampak terhadap loyalitas pelanggan, akan tetapi hasil penelitian yang dilakukan di Singaraja Futsal menunjukkan bahwa citra merek berpengaruh positif dan tidak signifikan terhadap loyalitas pelanggan. Hal ini disebabkan karena keyakinan terhadap suatu merek bisa dinikmati oleh pelanggan. Hasil ini diperkuat dengan penelitian yang dilakukan oleh Nelsen dan Donand (2017). Pengaruh citra merek terhadap loyalitas pelanggan. Menunjukkan hasil bahwa citra merek memberikan pengaruh positif signifikan terhadap loyalitas pelanggan.

Berdasarkan penelitian yang telah dilakukan menunjukkan bahwa harga berpengaruh positif dan tidak signifikan terhadap loyalitas pelanggan di Singaraja Futsal. Hasil ini menunjukkan dengan pertumbuhan harga yang meningkat akan berdampak terhadap loyalitas pelanggan, akan tetapi hasil penelitian yang dilakukan di Singaraja Futsal menunjukkan bahwa harga berpengaruh positif dan tidak signifikan terhadap loyalitas pelanggan. Halini disebabkan karena harga yang telah ditetapkan lebih kompetitif dari pesaing.

Hasil ini diperkuat dengan penelitian yang dilakukan oleh Nela, Fransiska dan Lukmanul Hakim (2015). Pengaruh harga terhadap loyalitas pelanggan. Menunjukkan hasil bahwa harga memberikan pengaruh positif signifikan terhadap loyalitas pelanggan

\section{SIMPULAN DAN SARAN SIMPULAN}

Berdasarkan paparan hasil penelitian dan pembahasan dapat disimpulkan sebagai berikut. (1) Citra merek dan harga berpengaruh signifikan terhadap loyalitas pelanggan sepatu merek Nike di Singaraja Futsal adalah dengan dengan citra merek dan harga yang dapat menyesuaikan maka pelanggang akan tetap loyal terhadap suatu merek. (2) Citra merek berpengaruh positif dan tidak signifikan terhadap loyalitas pelanggan sepatu merek Nike di Singaraja Futsal adalah citra merek kurang mampu mengikat daya tarik semua kalangan pelanggan. (3) Harga berpengaruh positif dan tidak signifikan terhadap loyalitas pelanggan sepatu merek Nike di Singaraja Futsal adalah harga yang berlebihan akan beresiko terhadap loyalitas pelanggan 


\section{SARAN}

Berdasarkan hasil penelitian dan pembahasan serta kesimpulan yang telah dipaparkan sebelumnya, maka dapat diajukan beberapa saran sebagai berikut. (1) Bagi perusahaan diharapkan pihak pemasar sepatu merek nike mempelajari lebih dalam mengenai loyalitas pelanggan yang dirasakan oleh pelanggan dengan mmperhatikan variabel citra merek dan harga. Dari penelitin ini diketahui bahwa variabel dominan mempengaruhi loyalitas pelanggan, sehingga pemasar sepatu merek nike lebih memperhatikan citra merek dan harga demi mencapai loyalits pelanggan (2) Bagi peneliti lain yang bermaksud melakukan penelitin di bidang manajemen pemasaran pada suatu perusahaan, diharapkan untuk melakukanpenelitian lebih lanjut dan mendalam terkait dengan pengaruh citra merek dan harga terhadap loyalitas pelanggan dengan metode penelitian yang sama dan perusahaan yang berbeda guna keberlakuan temuan ini secara lebih luas.

\section{DAFTAR PUSTAKA}

Aaker. David A., 2008, Strategic Market Management, Eight Edition, The Wiley BiicentennialKnowledge for Generation.

Alif, 2016. Pengaruh Citra Merek, Harga Dan Promosi Terhadap Loyalitas Konsumen. Sekolah Tinggi Ilmu Ekonomi Indonesia. Surabaya

Augusty, Ferdinand. 2006. Metode Penelitian Manajemen. Semarang: Badan Penerbit Universitas Diponegoro.

Kotler, Philip (2000). Prinsip - Prinsip Pemasaran Manajemen, Jakarta : Prenhalindo.

Kotler, Phillip. (2009). Manajemen Pemasaran, Edisi 13. Jakarta; Erlangga

Nela, Fransiska, dan Lukmanul Hakim. 2015. Analisis Pengaruh Harga, Citra Merek dan Kualitas Produk Terhadap Loyalitas Pengguna Smartphone Samsung di STIE Totalwin Semarang. Semarang: STIE Totalwin Semarang

Nelsen, Donant (2017)Penaruh Citra Merek Dan Harga Terhadap Loyalitas Pelanggan Air Minum Dalam Kemasan. Manajemen, Fakultas Bisnis Institute Teknologi dan Bisnis Kalbis, Jakarta.

Saladin, Djaslim. 2006. Manajemen Pemasaran Edisi Keempat. Bandung : Linda Karya.

Sugiyono, 2014. Metode Penelitian Bisnis (Pendekatan Kuantitatif, Kualitatif dan R\&D). Bandung: CV. Alfabeta.

Tjiptono, Fandy, 2000. Manajemen Jasa, edisi kedua, Andi, Yogyakarta 